\title{
Copper-Catalyzed Intramolecular C-H Alkoxylation of Diaryltriazoles: Synthesis of Tricyclic Triazole Benzoxazines
}

\author{
Xinyuan Ma, ${ }^{a}$ Haotian Li, ${ }^{a}$ Hong Xin, ${ }^{a}$ Weigen Du, ${ }^{a}$ Edward A. Anderson, ${ }^{* b}$ Xian Dong ${ }^{* c}$ and Yubo Jiang ${ }^{* a, b}$ \\ ${ }^{a}$ Faculty of Science, Kunming University of Science and Technology, Kunming 650500, China. \\ ${ }^{\mathrm{b}}$ Chemistry Research Laboratory, 12 Mansfield Road, Oxford, OX1 3TA, U.K. \\ ${ }^{\mathrm{c} C o l l e g e ~ o f ~ P h a r m a c e u t i c a l ~ S c i e n c e s, ~ Y u n n a n ~ U n i v e r s i t y ~ o f ~ C h i n e s e ~ M e d i c i n e, ~ K u n m i n g ~ 650500, ~ C h i n a . ~}$
}

ABSTRACT: An efficient copper-catalyzed intramolecular C-H alkoxylation of 1,4-disubstituted 1,2,3-triazoles has been developed. The
chemistry was applied to a wide range of substrates, generating tricyclic benzoxazine-fused 1,2,3-triazoles in good yields. Mechanistic studies
suggest that a radical pathway may be involved in this transformation. The triazole products were found to exhibit strong antifungal activity
against ginseng root-rot disease, demonstrating their potential as a scaffold in medicinal chemistry research.

1,2,3-Triazoles are readily accessible heterocycles that have found applications across organic chemistry, materials science, medicinal chemistry, and chemical biology. ${ }^{1-4}$ Novel triazole derivatives, such as polycyclic triazoles or those functionalized with additional heteroatom substituents, are of considerable interest due to potential uses in such fields. For example, while oxygenated sidechains can be introduced into 1,2,3-triazoles via cycloaddition-based approaches, ${ }^{5}$ triazoles in which an oxygen atom is directly attached to the heterocyclic core are significantly less common, ${ }^{6}$ not least as a cycloaddition disconnection would require the use of an ynol ether. Heteroatom substituents could significantly influence the physicochemical properties of the triazole ring, and as such methods for the synthesis of oxygenated triazoles are highly desirable.

Transition-metal-catalyzed $\mathrm{C}-\mathrm{H}$ functionalization is one of the most powerful methods to construct new $\mathrm{C}-\mathrm{X}$ bonds on aromatic and heteroaromatic rings, ${ }^{7}$ and triazoles have been widely used as directing groups for $\mathrm{C}-\mathrm{H}$ functionalization processes (Scheme 1, eq. 1) ${ }^{8}$ In contrast, there are few strategies for direct $\mathrm{C}-\mathrm{H}$ activation on the triazole ring itself, examples being limited to Pd-catalyzed alkenylation and arylation at the C5 position (Scheme 1, eq. 2), ${ }^{9}$ and to our previous report of an intramolecular silver-catalyzed C5acyloxylation that affords fused triazole isochromenones (Scheme 1, eq. 3). ${ }^{10}$

In light of the importance of novel heterocyclic scaffolds in medicinal chemistry, ${ }^{11}$ we targeted the development of other methods to achieve triazole $\mathrm{C}-\mathrm{H}$ functionalization. Here we report an efficient copper-catalyzed intramolecular $\mathrm{C}-\mathrm{O}$ bond formation at the 5-position of the 1,2,3-triazole ring to generate tricyclic triazole-benzoxazines (Scheme 1, eq. 4), and insight into the mechanism of this process. Triazole-containing compounds have been shown to exhibit antifungal activity against pathogens such as Candida albicans SC5314, Rhizoctonia solani, Gaeumannomyces graminsis and Cylindrocarpon destructans, ${ }^{12}$ and we also report the antifungal properties of the fused tricyclic triazoles prepared in this work against ginseng root-rot disease, which demonstrates the potential

Scheme 1. C-H Functionalization of 1,4-diaryl-1,2,3-triazoles.

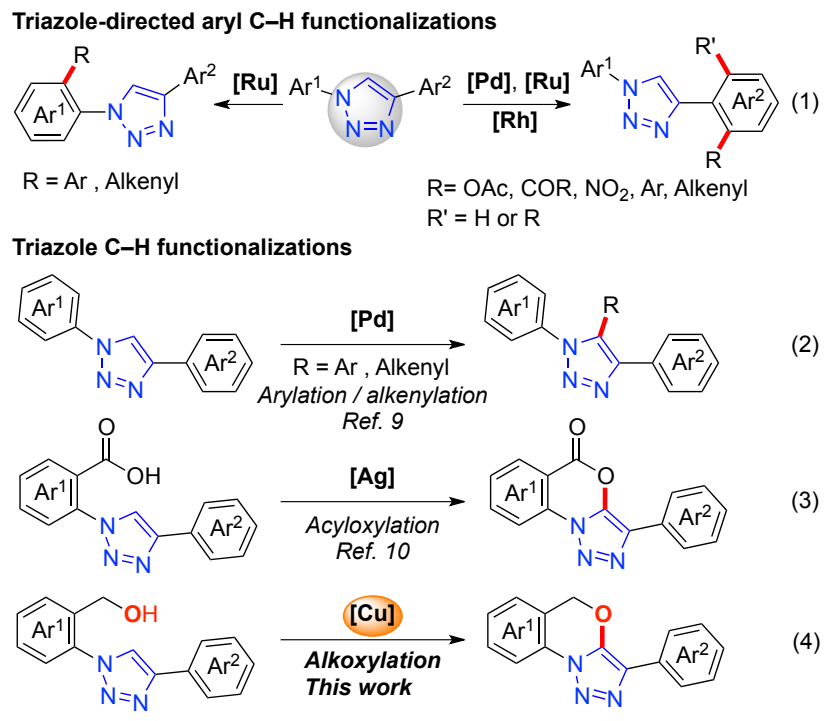

utility of this novel framework in biological settings.

At the outset of our studies, we selected 1,4-disubstituted 1,2,3triazole $1 \mathrm{a}$ as model substrate (Table 1). We questioned whether formation of an oxygen-centered radical could trigger $\mathrm{C}-\mathrm{O}$ alkoxylation of the triazole ring, in light of a related base-free $\mathrm{CuCl} /(t$ $\mathrm{BuO})_{2}$ mediated cyclization of (benz)imidazoles. ${ }^{13}$ However, after some experimentation, we found that not only was a base required to achieve cyclization, but also the additive tetrabutylammonium iodide (TBAI), which in combination with peroxide oxidants is known to be an effective radical initiator. ${ }^{14}$ Thus, in the presence of $20 \mathrm{~mol} \%$ $\mathrm{CuBr}, 10$ mol\% TBAI, 1.5 equivalents of di-tert-butyl hydroperoxide (DTBP) and 4.0 equivalents of $t$-BuOLi in DCE at $120^{\circ} \mathrm{C}$ under an $\mathrm{N}_{2}$ atmosphere, the intramolecular triazole alkoxylation product $2 \mathrm{a}$ was isolated in a pleasing $53 \%$ yield (Entry 1$).{ }^{15}$ Other oxidants $(t$ butyl hydroperoxide (TBHP) or $\mathrm{PhI}(\mathrm{OAc})_{2}$ ) led to inferior results (Entries 2, 3), while a solvent screen showed a

Table 1. Optimization of Reaction Conditions ${ }^{a}$ 


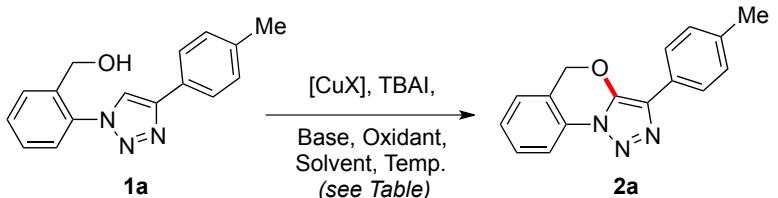

(see Table)

2a

$\begin{array}{ccccccc}\text { entry } & {[\mathrm{Cu}]} & \text { Base } & \text { Oxidant } & \text { Solvent } & \begin{array}{c}\text { Temp } \\ \left({ }^{\circ} \mathrm{C}\right)\end{array} & \begin{array}{c}\text { Yield } \\ (\%)\end{array} \\ 1 & \mathrm{CuBr} & t \text {-BuOLi } & \text { DTBP } & \text { DCE } & 120 & 53 \\ 2 & \mathrm{CuBr} & t \text {-BuOLi } & \mathrm{BAIB} & \mathrm{DCE} & 120 & <5 \\ 3 & \mathrm{CuBr} & t \text {-BuOLi } & \mathrm{TBHP} & \mathrm{DCE} & 120 & 13 \\ 4 & \mathrm{CuBr} & t \text {-BuOLi } & \mathrm{DTBP} & \mathrm{THF} & 120 & 35 \\ 5 & \mathrm{CuBr} & t \text {-BuOLi } & \mathrm{DTBP} & \mathrm{PhCF}_{3} & 120 & 45 \\ 6 & \mathrm{CuBr} & t \text {-BuOLi } & \mathrm{DTBP} & \mathrm{PhCH}_{3} & 120 & 57 \\ 7 & \mathrm{CuBr} & t \text {-BuOK } & \mathrm{DTBP} & \mathrm{PhCH}_{3} & 120 & 33 \\ 8 & \mathrm{CuBr} & t \text {-BuONa } & \mathrm{DTBP} & \mathrm{PhCH}_{3} & 120 & 27 \\ 9 & \mathrm{CuBr} & \mathrm{AcOLi} & \mathrm{DTBP} & \mathrm{PhCH}_{3} & 120 & 17 \\ 10 & \mathrm{CuBr} & t \text {-BuOLi } & \mathrm{DTBP} & \mathrm{PhCH}_{3} & 100 & 86 \\ 11 & \mathrm{CuBr} & t \text {-BuOLi } & \mathrm{DTBP} & \mathrm{PhCH}_{3} & 80 & 32 \\ 12 & \mathrm{CuCl} & t \text {-BuOLi } & \mathrm{DTBP} & \mathrm{PhCH}_{3} & 100 & 41 \\ 13 & \mathrm{CuI} & t \text {-BuOLi } & \mathrm{DTBP} & \mathrm{PhCH}_{3} & 100 & 45 \\ 14 & \mathrm{Cu}(\mathrm{acac})_{2} & t \text {-BuOLi } & \mathrm{DTBP} & \mathrm{PhCH}_{3} & 100 & 47 \\ 15 & \mathrm{CuBr} & t \text {-BuOLi } & - & \mathrm{PhCH}_{3} & 100 & 26 \\ 16 & \mathrm{CuBr} & - & \mathrm{DTBP} & \mathrm{PhCH}_{3} & 100 & 0 \\ 17 & \mathrm{CuBr} & t \text {-BuOLi } & \mathrm{DTBP} & \mathrm{PhCH}_{3} & 100 & 31 \\ 18 & - & t \text {-BuOLi } & \mathrm{DTBP} & \mathrm{PhCH}_{3} & 100 & 0\end{array}$

${ }^{a}$ Reaction conditions: $1 \mathrm{a}(0.3 \mathrm{mmol})$, copper salt $(20 \mathrm{~mol} \%)$, additive $(10 \mathrm{~mol} \%)$, base $(1.2 \mathrm{mmol})$ and oxidant $(0.45 \mathrm{mmol})$ in solvent $(2.0 \mathrm{~mL})$ under $\mathrm{N}_{2}$ at the stated temperature for $12 \mathrm{~h} .{ }^{b}$ Isolated yield. ${ }^{c}$ Conducted in the absence of TBAI.

modest improvement using toluene (57\%, Entries 4-6). Use of other bases ( $t$-BuONa, $t$-BuOK, and AcOLi) led to no improvement (Entries 7-9); however, reducing the reaction temperature to $100{ }^{\circ} \mathrm{C}$ led to a marked enhancement in yield ( $86 \%$, Entry 10$)$. These proved to be the optimal conditions, as other copper salts $(\mathrm{CuCl}, \mathrm{CuI}$, and $\left.\mathrm{Cu}(\mathrm{acac})_{2}\right)$ offered no advantage (Entries 12-14), while the need for $\mathrm{CuBr}, \mathrm{TBAI}$, base and oxidant was confirmed through control experiments (Entries 15-18).

With optimized conditions in hand, the scope of the alkoxylation reaction was studied for a range of 1,4-diaryl 1,2,3-triazoles (Figure 1). In general, electron-donating and moderately electron-withdrawing groups were accommodated at various positions on either aromatic ring, furnishing the tricyclic products in good yields $(\mathbf{2 a}$ $20,40-86 \%)$. While superior results were observed for para substituents, it is notable that ortho substitution afforded near-equivalent yields (compare $\mathbf{2 b} / \mathbf{2 c}$ and $\mathbf{2 n} / \mathbf{2 o}$ ), in spite of the increase in steric hindrance. Other noteworthy features are the tolerance of halogen substituents that would enable further product functionalization (such as bromide $2 \mathbf{k}$ and chlorides $\mathbf{2} \mathbf{i}-\mathbf{j}, 41-76 \%$ ), and heteroaromatic thiophene sidechains $2 \mathrm{l}$ and $2 \mathrm{~m}$, albeit the yield for the 2-thiophenyl group was lower $(40-65 \%)$. Finally, the novel isomeric fused triazole $2 \mathrm{p}$ could be formed from insertion of

Figure 1. Reaction Scope. ${ }^{2}$
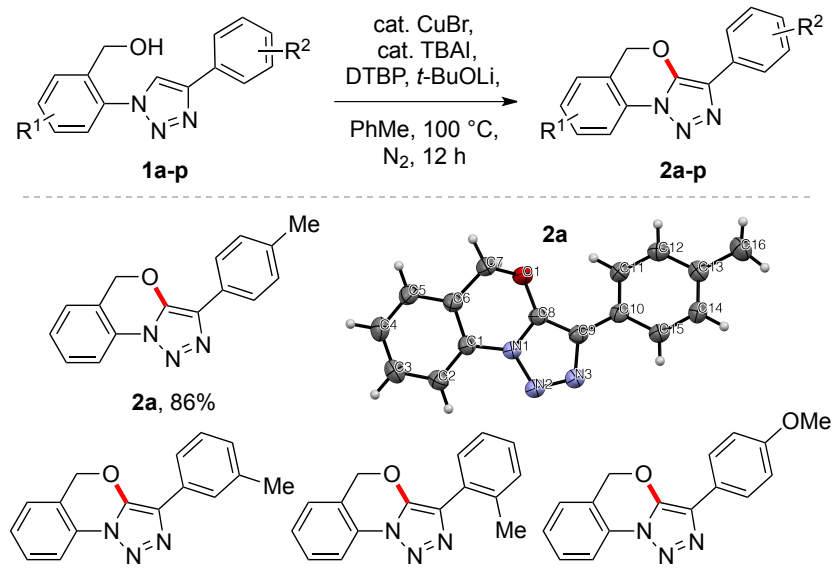

2b, $73 \%$

2c, $65 \%$

2d, $75 \%$
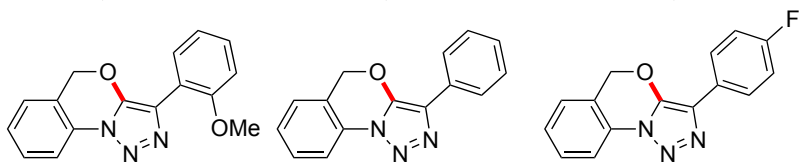

2 e, $62 \%$

2f, $68 \%$

2g, $73 \%$
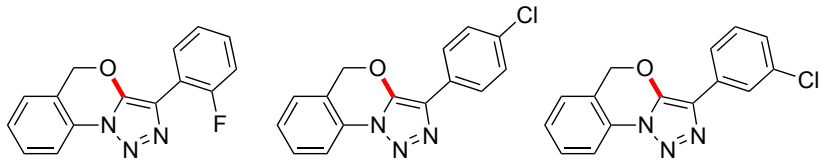

2h, $71 \%$

2i, $66 \%$

2j, $76 \%$
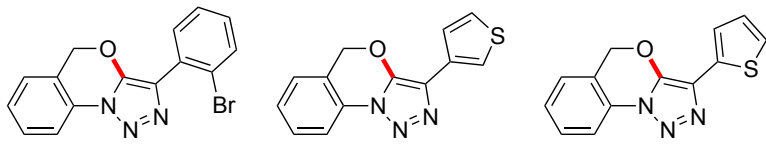

2k, $41 \%$

2I, $65 \%$

2m, $40 \%$

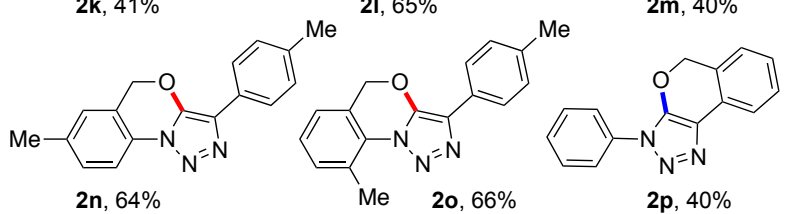

${ }^{a}$ Reaction conditions: $1(0.3 \mathrm{mmol})$, copper salt $(20 \mathrm{~mol} \%)$, TBAI (10 mol\%), $t$-BuOLi (1.2 mmol), DTBP (0.45 mmol), toluene (2.0 $\mathrm{mL}), \mathrm{N}_{2}, 100^{\circ} \mathrm{C}, 12 \mathrm{~h}$. Yields are isolated yields. Ellipsoids for the single crystal X-ray structure of $\mathbf{2 a}$ are shown at $50 \%$ probability.

a benzylic alcohol on the 4-aryl group, rather than 1-aryl.

Two experiments were performed to gain insight into the mechanism of this novel C-H alkoxylation (Scheme 2). Performing the reaction under optimized conditions, but in the presence of TEMPO or $\mathrm{BHT}$, resulted in complete inhibition of the formation of $\mathbf{2 a}$ (Scheme $2 \mathrm{a}$ ), which suggests that the reaction may indeed proceed through a radical pathway; in addition, a product of alkoxyl radical trapping (3) was isolated in 54\% yield using BHT as inhibitor. A kinetic isotope effect $\left(k_{\mathrm{H}} / k_{\triangleright}\right)$ of $\sim 1.0$ was observed for the reaction of 1f relative to $\boldsymbol{d}_{6}-\mathbf{1 f}$ (Scheme $2 \mathrm{~b}$ ), which suggests that $\mathrm{C}-\mathrm{H} / \mathrm{D}$ bond cleavage is not involved in the rate limiting step.

Based on these results and related literature precedent, ${ }^{16}$ a possible reaction mechanism is outlined in Scheme 3. First, single-electron oxidation of $\mathrm{Cu}(\mathrm{I})$ by DTBP would generate $\mathrm{Cu}(\mathrm{II}), t-\mathrm{BuO}^{-}$, and $\mathrm{t}-\mathrm{BuO}^{\circ}$. Deprotonation of the benzylic alcohol leads to $\mathrm{Cu}$ (II)alkoxide $\mathbf{A}$, which disproportionates to alkoxide radical $\mathbf{B}$ and $\mathrm{Cu}(\mathrm{I})$ via SET to the metal. ${ }^{16 \mathrm{~d}}$ Addition of the alkoxyl radical to the $\mathrm{C} 5$ position of the triazole affords carbon-centered radical $\mathrm{C}$,

Scheme 2. a. Radical Inhibition Experiments and b. Kinetic Isotope Effect Study. 


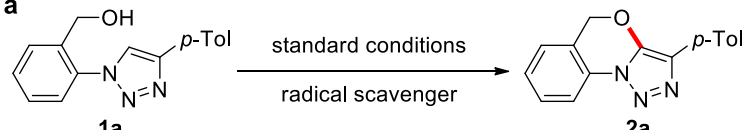

$1 \mathrm{a}$

Radical scavenger: TEMPO BHT Yield of $2 \mathrm{a}(\%): \quad<5 \quad 0$
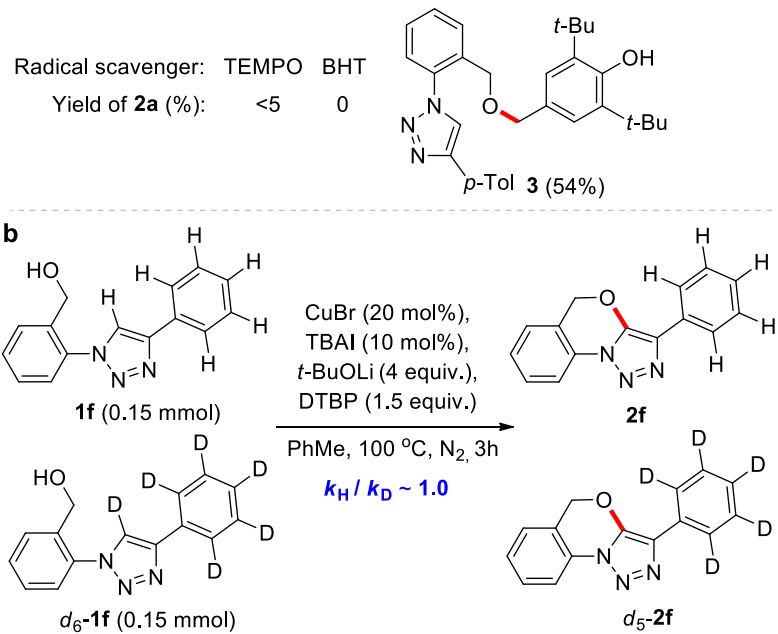

which is transformed to product $\mathbf{2}$ on reaction with the tert-butoxyl radical, or oxidation by $\mathrm{Cu}(\mathrm{II})$ followed by aromatization (Scheme 3). ${ }^{16}$

The tricyclic fused ring triazole products $\mathbf{2}$ have potential utility in medicinal and agrochemistry as novel heterocyclic scaffolds. In light of the known antifungal activity of other triazoles, ${ }^{12}$ we evaluated the antifungal properties of $\mathbf{2 a - 0}$ against three fungal strains ( $F$. oxysporum, F. solani, and C. destructans), which are the main pathogenic fungi associated with ginseng root-rot disease, using the microbroth dilution technique (Table 2). ${ }^{17}$ Pleasingly, several compounds showed promising levels of inhibition of $F$. oxysporum compared to existing antifungal agents. $2 \mathrm{c}$ in particular exhibited excellent activity against all strains. Several compounds (2e-g, $2 \mathbf{j}-2 \mathrm{~m})$ showed good inhibitory activity against $F$. oxysporum, while 21 also exhibited activity against $C$. destructans. $2 \mathrm{n}$ and $\mathbf{2 o}$ showed selectivity for the latter.

In conclusion, a simple and efficient protocol for the synthesis of tricyclic triazole-benzoxazines via copper-catalyzed intramolecular $\mathrm{C}-\mathrm{H}$ triazole alkoxylation has been developed. To the best of our knowledge, this is the first example of transition metal-catalyzed C5 alkoxylation of the 1,2,3-triazole ring, a heterocycle which is itself commonly regarded as a useful $\mathrm{C}-\mathrm{H}$ functionalization directing

Scheme 3. Possible Reaction Mechanism.

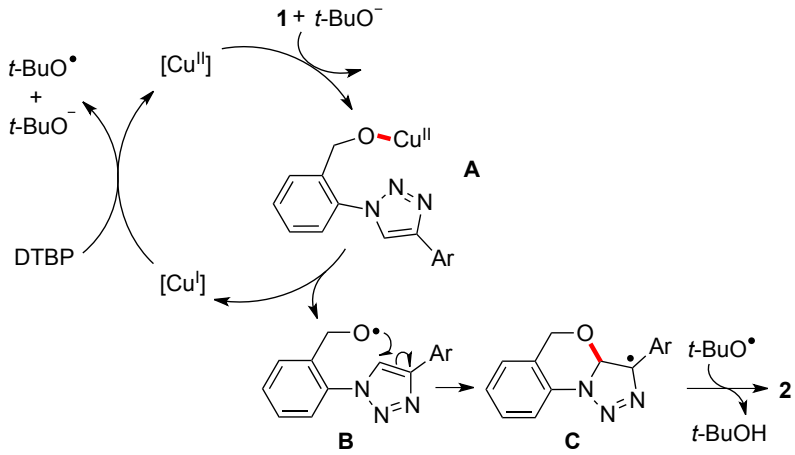

Table 2. Antifungal properties of compounds $2 \mathrm{a}-20{ }^{2}$

\begin{tabular}{ccccc} 
entry & triazole & F. oxysporum & F. solani & C. destructans \\
\hline 1 & $2 \mathrm{a}$ & $150.0 \pm 0.0$ & $>150.0$ & $>150.0$ \\
2 & $2 \mathrm{~b}$ & $>150.0$ & $>150.0$ & $>150.0$ \\
3 & $2 \mathrm{c}$ & $2.1 \pm 0.3$ & $94.0 \pm 18.8$ & $93.7 \pm 18.8$ \\
4 & $2 \mathrm{e}$ & $9.4 \pm 0.0$ & $>150.0$ & $>150.0$ \\
5 & $2 \mathrm{f}$ & $10.0 \pm 2.0$ & $>150.0$ & $>150.0$ \\
6 & $2 \mathrm{~g}$ & $1.2 \pm 0.0$ & $>150.0$ & $>150.0$ \\
7 & $2 \mathrm{~h}$ & $>150.0$ & $>150.0$ & $>150.0$ \\
8 & $2 \mathrm{i}$ & $150 \pm 0.0$ & $>150.0$ & $>150.0$ \\
9 & $2 \mathrm{j}$ & $9.4 \pm 0.0$ & $>150.0$ & $>150.0$ \\
10 & $2 \mathrm{k}$ & $13.1 \pm 2.2$ & $>150.0$ & $>150.0$ \\
11 & $2 \mathrm{l}$ & $37.5 \pm 0.0$ & $150.0 \pm 0.0$ & $65.6 \pm 9.4$ \\
12 & $2 \mathrm{~m}$ & $3.3 \pm 0.6$ & $>150.0$ & $>150.0$ \\
13 & $2 \mathrm{n}$ & $150.0 \pm 0.0$ & $>150.0$ & $37.3 \pm 0.0$ \\
14 & $2 \mathrm{o}$ & $>150.0$ & $>150.0$ & $23.4 \pm 4.7$ \\
$15^{b}$ & Hymexazol & $50.0 \pm 13.0$ & $12.5 \pm 3.1$ & $12.5 \pm 3.1$ \\
$16^{b}$ & Flutriafol & $37.5 \pm 0.0$ & $135.0 \pm 15.0$ & $3.8 \pm 0.6$ \\
$17^{b}$ & Grondverbeter- & $>150.0$ & $>150.0$ & $75.0 \pm 0.0$ \\
& aar & & & $150.0 \pm 0.0$ \\
$18^{b}$ & Propamocarb & $150.0 \pm 0.0$ & $>150.0$ &
\end{tabular}

${ }^{a} \mathrm{MIC}$ values are given in $\mu \mathrm{g} / \mathrm{mL} .{ }^{b}$ Positive controls.

group. These tricyclic structures show potential as novel scaffolds in medicinal chemistry, here evidenced by their marked antifungal activity against $F$. oxysporum, $F$. solani, and $C$. destructans, the causal pathogens of ginseng root-rot disease.

\section{ASSOCIATED CONTENT}

\section{Supporting Information}

The Supporting Information is available free of charge on the ACS Publications website. Experimental procedures, mechanistic studies, copies of ${ }^{1} \mathrm{H}$ and ${ }^{13} \mathrm{C}$ NMR spectra (PDF) and crystallographic data (CIF).

\section{AUTHOR INFORMATION}

\section{Corresponding Authors}

*E-mail: ybjiang@kust.edu.cn; edward.anderson@chem.ox.ac.uk; dongxian_1655129@163.com.

\section{ORCID}

Edward A. Anderson: 0000-0002-4149-0494

Yubo Jiang: 0000-0002-6066-4613

Xian Dong: 0000-0001-7639-1800

Notes

The authors declare no competing financial interest.

\section{ACKNOWLEDGMENT}

We are grateful to the National Natural Science Foundation of China (No. 21662020) and the China Scholarship Council (No. 201908535023) for the financial support. E.A.A. thanks the EPSRC for support (EP/S013172/1).

\section{REFERENCES}


(1) (a) Kolb, H. C.; Finn, M. G.; Sharpless, K. B., Click chemistry: diverse chemical function from a few good reactions. Angew. Chem., Int. Ed. 2001, 40, 2004-2021; (b) Meldal, M.; Tornoe, C. W., Cu-Catalyzed azide-alkyne cycloaddition. Chem. Rev. 2008, 108, 2952-3015; (c) Becer, C. R.; Hoogenboom R.; Schubert, U. S., Click chemistry beyond metal-catalyzed cycloaddition. Angew. Chem., Int. Ed. 2009, 48, 4900-4908.

(2) (a) Moses, J. E.; Moorhouse, A. D., The growing applications of click chemistry. Chem. Soc. Rev. 2007, 36, 1249-1262; (b) Hein, J. E.; Fokin, V. V., Copper-catalyzed azide-alkyne cycloaddition (CuAAC) and beyond: new reactivity of copper(I) acetylides. Chem. Soc. Rev. 2010, 39, 13021315; (c) Kumar, A. S.; Ghule, V. D.; Subrahmanyam, S.; Sahoo, A. K., Synthesis of thermally stable energetic 1,2,3-triazole derivatives. Chem. -Eur. J. 2013, 19, 509-518.

(3) (a) Lutz, J.-F., 1,3-Dipolar cycloadditions of azides and alkynes: a universal ligation tool in polymer and materials science. Angew. Chem., Int. Ed. 2007, 46, 1018-1025; (b) Hong, V.; Presolski, S. I.; Ma, C.; Finn, M. G., Analysis and optimization of copper-catalyzed azide-alkyne cycloaddition for bioconjugation. Angew. Chem., Int. Ed. 2009, 48, 9879-9883; (c) Hong S. Y.; Tobias, G.; Al-Jamal, K. T.; Ballesteros, B.; Ali-Boucetta, H.; LozanoPerez, S.; Nellist, P. D.; Sim, R. B.; Mather, S. J.; Green, M. L. H.; Kostarelos, K.; Davis, B. G.; Finucane, C., Filled and glycosylated carbon nanotubes for in vivo radio-emitter localization and imaging. Nat. Mater. 2010, 9, 485-490; (d) Besanceney-Webler, C.; Jiang, H.; Zheng, T.; Feng, L.; Soriano del Amo, D.; Wang, W.; Klivansky, L. M.; Marlow, F. L.; Liu, Y.; Wu, P., Increasing the efficacy of bioorthogonal click reactions for bioconjugation: a comparative study. Angew. Chem., Int. Ed.2011, 50, 8051-8056; (e) Zhou, Q.; Gui, J.; Pan, C.-M.; Albone, E.; Cheng, X.; Suh, E. M.; Grasso, L.; Ishihara Y.; Baran, P. S., Bioconjugation by native chemical tagging of C-H bonds. J. Am. Chem. Soc. 2013, 135, 12994-12997; (f) Tiwari, V. K.; Mishra, B. B.; Mishra, K. B.; Mishra, N.; Singh, A. S.; Chen, X., Cu-Catalyzed click reaction in carbohydrate chemistry. Chem. Rev. 2016, 116, 3086-3240.

(4) (a) Pagliai, F.; Pirali, T.; Del Grosso, E.; Di Brisco, R.; Tron, G. C.; Sorba, G.; Genazzani, A. A., Rapid synthesis of triazole-modified resveratrol analogues via click chemistry. J. Med. Chem. 2006, 49, 467-470; (b) Kim, W. G.; Choi, B.; Yang, H.-J.; Han, J.-A.; Jung, H.; Cho, H.; Kang, S.; Hong, S. Y., Covalent conjugation of small-molecule adjuvants to nanopar-ticles induces robust cytotoxic $\mathrm{T}$ cell responses via $\mathrm{DC}$ activation. Bioconjugate Chem. 2016, 27, 2007-2013; (c) Giroud, M.; Kuhn, B.; Saint-Auret, S.; Kuratli, C.; Martin, R. E.; Schuler, F.; Diederich, F.; Kaiser, M.; Brun, R.; Schirmeister, T.; Haap, W., $2 H$-1,2,3-Triazole-based dipeptidyl nitriles: potent, selective, and trypanocidal rhodesain inhibitors by structure-based design. J. Med. Chem. 2018, 61, 3370-3388; (d) Liu, J.; Ren, Z.; Fan, L.; Wei, J.; Tang, X.; Xu, X.; Yang, D., Design, synthesis, biological evaluation, structure-activity relationship, and toxicity of clinafloxacin-azole conjugates as novel antitubercular agents. Bioorg. Med. Chem. 2019, 27, 175-187.

(5) (a) Park, I. S.; Kwon, M. S.; Kim, Y.; Lee, J. S.; Park, J., Heterogeneous copper catalyst for the cycloaddition of azides and alkynes without additives under ambient conditions. Org. Lett., 2008, 10, 497-500; (b) Karan, C. K.; Sau, M. C.; Bhattacharjee, M., A copper(II) metal-organic hydrogel as a multifunctional precatalyst for CuAAC reactions and chemical fixation of CO2 under solvent free conditions. Chem. Commun., 2017, 53, 1526-1529; (c) Xiang, F.; Li, B.; Zhao, P.; Tan, J.; Yu, Y.; Zhang, S., Copper(I)-chelated cross-linked cyclen micelles as a nanocatalyst for azide-alkyne cycloaddition in both water and cells. Adv. Synth. Catal., 2019, 361, 5057-5062.

(6) (a) Creary, X.; Anderson, A.; Brophy, C.; Crowell, F.; Funk, Z., Method for assigning structure of 1,2,3-triazoles. J. Org. Chem. 2012, 77, 8756-8761 (b) Alford, J. S.; Davies, H. M. L., Mild aminoacylation of indoles and pyrroles through a three-component reaction with ynol ethers and sulfonyl azides. J. Am. Chem. Soc. 2014, 136, 10266-10269; (c) Cisneros, J. A.; Robertson, M. J.; Valhondo, M.; Jorgensen, W. L., A fluorescence polarization assay for binding to macrophage migration inhibitory factor and crystal structures for complexes of two potent inhibitors. J. Am. Chem. Soc. 2016, 138, 8630-8638; (d) Amini, A.; Fallah, A.; Cheng, C.; Tajbakhsh, M., Natural phosphate-supported $\mathrm{Cu}$ (II), an efficient and recyclable catalyst for the synthesis of xanthene and 1,4-disubstituted-1,2,3-triazole derivatives. RSC Adv. 2018, 8, 41536-41547.

(7) For selected recent reviews on C-H funtionalization, see: (a) Colby, D. A.; Bergman, R. G.; Ellman, J. A., Rhodium-catalyzed C-C bond formation via heteroatom-directed C-H bond activation. Chem. Rev. 2010, 110, 624-655; (b) Bras, J. L.; Muzart, J., Intermolecular dehydrogenative Heck reactions. Chem. Rev. 2011, 111, 1170-1214; (c) Yeung, C. S.; Dong, V. M., Catalytic dehydrogenative cross-coupling: forming carbon-carbon bonds by oxidizing two carbon-hydrogen bonds. Chem. Rev. 2011, 111, 1215-1292; (d) Sun, C.-L.; Li, B.-J.;. Shi, Z.-J., Direct C-H transformation via iron catalysis. Chem. Rev. 2011, 111, 1293-1314; (e) Liu, C.; Zhang, H.; Shi, W.; Lei, A., Bond formations between two nucleophiles: transition metal catalyzed oxidative cross-coupling reactions. Chem. Rev. 2011, 111, 17801824; (f) Allen, S. E.; Walvoord, R. R.; Padilla-Salinas, R.; Kozlowski, M. C., Aerobic copper-catalyzed organic reactions. Chem. Rev. 2013, 113, 62346458; (g) Arockiam, P. B.; Bruneau, C.; Dixneuf, P. H., Ruthenium(II)catalyzed C-H bond activation and functionalization. Chem. Rev. 2012, 112, 5879-5918; (h) Ackermann, L., Carboxylate-assisted ruthenium-catalyzed alkyne annulations by $\mathrm{C}-\mathrm{H} / \mathrm{Het}-\mathrm{H}$ bond functionalizations. Acc. Chem. Res. 2014, 47, 281-295; (i) Hartwig, J. F., Borylation and silylation of C-H bonds: a platform for diverse C-H bond functionalizations. Acc. Chem. Res. 2012, 45, 864-873; (j) Wang, T.; Jiao, N., Direct approaches to nitriles via highly efficient nitrogenation strategy through $\mathrm{C}-\mathrm{H}$ or $\mathrm{C}-\mathrm{C}$ bond cleavage. Acc. Chem. Res. 2014, 47, 1137-1145; (k) Ye, B.; Cramer, N., Chiral cyclopentadienyls: enabling ligands for asymmetric $\mathrm{Rh}(\mathrm{III})$-catalyzed $\mathrm{C}-\mathrm{H}$ functionalizations. Acc. Chem. Res. 2015, 48, 1308-1318; (1) Yang, L.; Huang, H., Transition-metal-catalyzed direct addition of unactivated C-H bonds to polar unsaturated bonds. Chem. Rev. 2015, 115, 3468-3517; (m) Cheng, C.; Hartwig, J. F., Catalytic silylation of unactivated C-H bonds. Chem. Rev. 2015, 115, 8946-8975; (n) Gulías, M.; Mascareñas, J. L., Metal-catalyzed annulations through activation and cleavage of C-H bonds. Angew. Chem., Int. Ed. 2016, 55, 11000-11019; (o) Yi, H.; Zhang, G.; Wang, H.; Huang, Z.; Wang, J.; Singh, A. K.; Lei, A., Recent advances in radical C-H activation/radical cross-coupling. Chem. Rev. 2017, 117, 9016-9085; (p) He, J.; Wasa, M.; Chan, K. S. L.; Shao, Q.; Yu, J.-Q., Palladium-catalyzed transformations of alkyl C-H bonds. Chem. Rev. 2017, 117, 8754-8786; (q) Gandeepan, P.; Mueller, T.; Zell, D.; Cera, G.; Warratz, S.; Ackermann, L., 3d Transition metals for C-H activation. Chem. Rev. 2019, 119, 2192-2452; (r) Wang, J.; Dong, G., Palladium/norbornene cooperative catalysis. Chem. Rev. 2019, 119, 7478-7528; (s) Rej, S.; Ano, Y.; Chatani, N., Bidentate directing groups: An efficient tool in $\mathrm{C}-\mathrm{H}$ bond functionalization chemistry for the expedient construction of C-C bonds. Chem. Rev. 2020, 120, 1788-1887.

(8) (a) Ackermann, L.; Vicente, R.; Althammer, A., Assisted rutheniumcatalyzed C-H bond activation: carboxylic acids as cocatalysts for generally applicable direct arylations in apolar solvents. Org. Lett. 2008, 10, 22992302; (b) Li, X. G.; Liu, K.; Zou, G.; Liu, P. N., Ruthenium-catalyzed alkenylation of arenes with alkynes or alkenes by 1,2,3-triazole-directed C-H activation. Eur.J. Org. Chem. 2014, 7878-7888; (c) Tirler, C.; Ackermann, L., Ruthenium(II)-catalyzed cross-dehydrogenative C-H alkenylations by triazole assistance. Tetrahedron 2015, 71, 4543-4551; (d) Zhao, S.; Yu, R.; Chen, W.; Liu, M.; Wu, H., Efficient approach to mesoionic triazolo[5,1a] isoquinolium through rhodium-catalyzed annulation of triazoles and internal alkynes. Org. Lett. 2015, 17, 2828-2833; (e) Zhao, F.; Chen, Z.; Liu, Y.; Xie, K.; Jiang, Y., Palladium-catalyzed acylation of arenes by 1,2,3-triazole-directed C-H activation. Eur.J. Org. Chem. 2016, 5971-5979; (f) Zhao, F.; Chen, Z.; Huang, S.; Jiang, Y., Palladium-catalyzed nitration of arenes by 1,2,3-triazole-directed C-H activation. Synthesis 2016, 48, 2105-2111; (g) Irastorza, A.; Aizpurua, J. M.; Correa, A., Triazole-directed Pd-catalyzed C(sp2)-H oxygenation of arenes and alkenes. Org. Lett. 2016, 18, 10801083; (h) Zhao, F.; Chen, Z.; Ma, X.; Huang, S.; Jiang, Y., Palladium-catalyzed acetoxylation of arenes by 1,2,3-triazole-directed C-H activation. Tetrahedron Lett. 2017, 58, 614-617; (i) Jiang, Y.; Ma, X.; Zhao, F.; Han, C., Palladium-catalyzed C-H acylation of arenes directed by 1,2,3-triazole. Synlett 2017, 28, 713-718; (j) Goitia, A.; Gómez-Bengoa, E.; Correa, A., Selective C(sp2)-H halogenation of "Click" 4-aryl-1,2,3-triazoles. Org. Lett. 2017, 19, 962-965; (k) Shen, Z.; Cera, G.; Haven, T.; Ackermann, L., Tri-substituted triazole-enabled $\mathrm{C}-\mathrm{H}$ activation of benzyl and aryl amines by iron catalysis. Org. Lett.2017, 19, 3795-3798; (1) Zhao, F.; Liu, Y.; Yang, S.; Xie, K.; Jiang, Y., Pd-catalyzed selective N(3)-ortho C-H arylation of 1,4-disubstituted 1,2,3-triazoles. Org. Chem. Front. 2017, 4, 1112-1115; (m) Guerrero, I.; Correa, A., Metal-catalyzed C-H functionalization processes with "Click"triazole assistance. Eur. J. Org. Chem. 2018, 6034-6049; (n) Wang, H.; Yi, 
X.; Cui, Y.; Chen, W., Rhodium-catalyzed triazole-directed C-H bond functionalization of arenes with diazo compounds. Org. Biomol. Chem. 2018, 16, 8191-8195; (o) Yu, Z.-J.; Zhang, C.; Li, J.-L.; Liu, Y.-Z.; Yu, X.-L.; Guo, L.; Li, G.-B.; Wu, Y., Rh(III)-catalyzed, 1,2,3-triazole-assisted directed C-H coupling with diazo diphosphonates. Tetrahedron Lett. 2018, 59, 28162819; (p) Sang, R.; Zheng, Y.; Zhang, H.; Wu, X.; Wang, Q.; Hai, L.; Wu, Y., Palladium-catalyzed direct $\mathrm{C}-\mathrm{H}$ ethoxycarbonylation of 2-aryl-1,2,3-triazoles and efficient synthesis of suvorexant. Org. Chem. Front. 2018, 5, 648652; (q) Ma, X.; Du, W.; Liu, W.; Liu, Y.; Xiao, T.; Jiang, Y., Metal-free selective aryl C-H formylation co-controlled by 1,2,3-triazole and hydroxyl using DMSO as formyl source. J. Chem. Sci. 2019, 131, 1-7.

(9) (a) Ackermann, L.; Potukuchi, H. K.; Landsberg, D.; Vicente, R. Copper-catalyzed "Click" reaction/direct arylation sequence: Modular syntheses of 1,2,3-triazoles. Org. Lett. 2008, 10,3081-3084; (b) Ackermann, L.; Althammer, A.; Fenner, S., Palladium-catalyzed direct arylations of heteroarenes with tosylates and mesylates. Angew. Chem. Int. Ed. 2009, 48, 201-204; (c) Ackermann, L.; Jeyachandran, R.; Potukuchi, H.; Novak, P.; Buttner, L., Palladium-catalyzed dehydrogenative direct arylations of 1,2,3triazoles. Org. Lett. 2010, 12, 2056-2059; (d) Jiang, H.; Feng, Z.; Wang, A.; Liu, X.; Chen, Z., Palladium-catalyzed alkenylation of 1,2,3-triazoles with terminal conjugated alkenes by direct $\mathrm{C}-\mathrm{H}$ bond functionalization. Eur. J. Org. Chem. 2010, 1227-1230; (e) Ackermann, L.; Potukuchi, H., Regioselective syntheses of fully-substituted 1,2,3-triazoles: the CuAAC/C-H bond functionalization nexus. Org. Biomol. Chem. 2010, 8, 4503-4513.

(10) Liu, Y.; Zhang, W.; Xie, K.; Jiang, Y., Silver-catalyzed intramolecular C(5)-H acyloxylation of 1,4-disubstituted 1,2,3-triazoles. Synlett 2017, 28, 1496-1500.

(11) (a) W. Pitt, R.; Parry, D. M.; Perry, B. G.; Groom, C. R., Heteroaromatic rings of the future. J. Med. Chem., 2009, 52, 2952-2963; (b) Taylor, R. D.; MacCoss, M.; Lawson, A. D. G., Rings in drugs. J. Med. Chem. 2014, 57, 5845-5859.

(12) (a) Yu, S.; Wang, L.; Wang, Y.; Song, Y.; Cao, Y.; Jiang, Y.; Sun, Q.; $\mathrm{Wu}, \mathrm{Q}$., Molecular docking, design, synthesis and antifungal activity study of novel triazole derivatives containing the 1,2,3-triazole group. RSC Adv. 2013, 3, 13486-13490; (b) He, J.; He, H.; Zhao, L.; Zhang, L.; You, G.; Feng, L.; Wan, J.; He, H., Synthesis and antifungal activity of 5-iodo-1,4-disubstituted-1,2,3-triazole derivatives as pyruvate dehydrogenase complex E1 inhibitors. Bioorg. Med. Chem. 2015, 23, 1395-1401; (c) Yan, W.; Wang, X.; Li, K.; Li, T.; Wang, J.; Yao, K.; Cao, L.; Zhao, S.; Ye, Y., Design, synthesis, and antifungal activity of carboxamide derivatives possessing 1,2,3-triazole as potential succinate dehydrogenase inhibitors. Pestic. Biochem. Phys. 2019, 156, 160-169; (d) Ren, Y.; Liu, Y.; Gao, S.; Dong, X.; Xiao, T.; Jiang, Y., Palladium-catalyzed selective ortho $\mathrm{C}-\mathrm{H}$ alkoxylation at 4-aryl of 1, 4-disubstituted 1, 2, 3-triazoles. Tetrahedron 2020, 76, 130985-130989.

(13) Takemura, N.; Kuninobu, Y.; Kanai, M., Copper-Catalyzed CH Alkoxylation of Azoles. Org. Lett. 2013, 15, 844-847.

(14) (a) Wu, X.; Gong, J.; Qi, X., A powerful combination: recent achievements on using TBAI and TBHP as oxidation system. Org. Biomol. Chem. 2014, 12, 5807-5817; (b) Achar, T. K.; Mal, P., Radical-induced metal and solvent-free cross-coupling using TBAI-TBHP: Oxidative amidation of aldehydes and alcohols with $\mathrm{N}^{-}$chloramines via $\mathrm{C}-\mathrm{H}$ activation. J. Org. Chem. 2015, 80, 666-672; (c) Laha, J. K.; Jethava, K. P.; Patel, S.; Patel, K. V., Intramolecular acylation of unactivated pyridines or arenes via multiple $\mathrm{C}-\mathrm{H}$ functionalizations: Synthesis of all four azafluorenones and fluorenones. J. Org. Chem. 2017, 82, 76-85.

(15) The structure of $\mathbf{2 a}$ was unambiguously determined by single-crystal X-ray analysis. CCDC 1881658 contains the supplementary crystallographic data. These data can be obtained free of charge from The Cambridge Crystallographic Data Centre via www.ccdc.cam.ac.uk/data request/cif.

(16) (a) King, A. E.; Huffman, L. M.; Casitas, A.; Costas, X.; Ribas, M.; Stahl, S. S., Copper-catalyzed aerobic oxidative functionalization of an arene C-H bond: evidence for an aryl-copper(III) intermediate. J. Am. Chem. Soc. 2010, 132, 12068-12073; (b) Takamatsu, K.; Hirano, K.; Miura, M., Copper-mediated decarboxylative coupling of benzamides with ortho-nitrobenzoic acids by directed C-H cleavage. Angew. Chem., Int. Ed. 2017, 56, 5353; (c) Yang, Q.-L.; Wang, X.-Y.; Lu, J.-Y.; Zhang, L.-P.; Fang, P.; Mei, T.-S., Copper-catalyzed electrochemical $\mathrm{C}-\mathrm{H}$ amination of arenes with secondary amines. J. Am. Chem. Soc. 2018, 140, 11487-11494; (d) Ren, H.; Song, J.R.; Li, Z.-Y.; Pan, W.-D., Oxazoline-/copper-catalyzed alkoxyl radical generation: solvent-switched to access 3a,3a'-bisfuroindoline and 3-alkoxyl furoindoline. Org. Lett. 2019, 21, 6774-6778.

(17) (a) Chalasani, A. G.; Dhanarajan, G.; Nema, S.; Sen, R.; Roy, U., An antimicrobial metabolite from bacillus sp.: significant activity against pathogenic bacteria including multidrug-resistant clinical strains. Front. Microbiol. 2015, 6, 1335-1344; (b) Ma, Y.-N.; Xu, F.-R.; Chen, C.-J.; Li, Q.-Q.; Wang, M.-Z.; Cheng, Y.-X.; Dong, X., The beneficial use of essential oils from buds and fruit of Syzygium aromaticum to combat pathogenic fungi of Panax notoginseng. Ind. Crops Prod. 2019, 133, 185-192.

\section{TOC entry:}
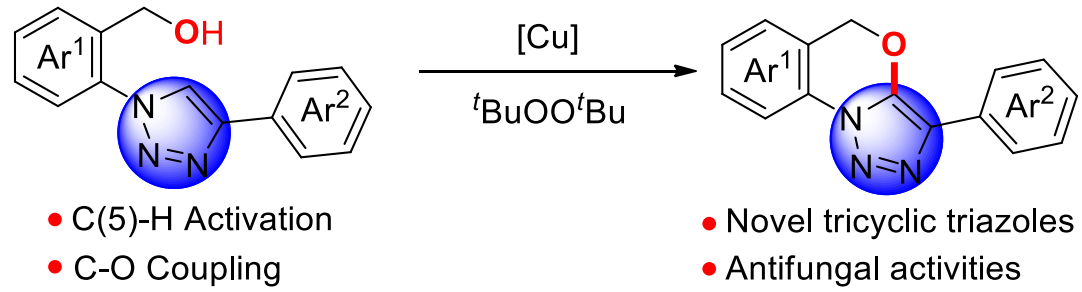